\title{
The dynamics of volunteer motivations for engaging in the management of invasive plants: Insights from a mixed-methods study on Scottish seabird islands.
}

\author{
Marie Pagès ${ }^{1,2}$, Anke Fischer ${ }^{2}$, René van der $\mathrm{Wal}^{1}$ \\ ${ }^{1}$ Institute for Biological and Environmental Sciences (IBES) - Ecology and Evolution, \\ University of Aberdeen, Aberdeen, United Kingdom; ${ }^{2}$ The James Hutton Institute, \\ Social, Economic and Geographical Sciences, Craigiebuckler, Aberdeen, United \\ Kingdom
}

Volunteers play an important role in the management of natural habitats. Understanding what motivates volunteers to join conservation initiatives and how motivations change over time is essential to enhance the environmental and social benefits of their engagement. Using a repeated qualitative survey and semistructured interviews, we explore volunteers' initial and sustained motivations in the management of the invasive tree mallow (Lavatera arborea) on Scottish seabird islands. Caring for nature, the performance of volunteering activities, and social interactions were the main drivers of involvement. Over time, motivations were shaped by the interplay between individual expectations and experiences with the social and ecological context. They changed from identifiable functions to more complex attachments to the place and the group. We discuss the limitations of functional methodologies in making sense of these attachments and of the performative nature of environmental volunteering. We then explore the practical implications of the dynamics of volunteering motivations.

Keywords: volunteering; motivations; functionalism; invasive species, habitat restoration

\section{Introduction}

Volunteers have played an increasing role in restoring and monitoring the natural environment in the past decades (Lorimer 2010; Conrad and Hilchey 2011; Tulloch et 
al. 2013). An example of the growing importance of volunteerism in the delivery of nature conservation policies concerns the role of local stakeholders and the general public in the sustained, yet affordable, management of biological invasions (Bryce et al. 2011; Crall et al. 2011; Ford-Thompson et al. 2012). Invasive non-native species are organisms introduced by humans outside their native range that threaten ecosystems, habitats, and species (Convention on Biological Diversity 2002). INNS are considered to be major drivers of global environmental change and one of the most serious issues affecting biodiversity conservation (Millennium Ecosystem Assessment 2005; Simberloff et al. 2013).

Volunteering is defined here as an unpaid, non-obligated activity that aims to benefit other individuals and groups (Penner 2004) or to improve the environment. This paper focuses on the motivations driving volunteers' initial and on-going involvement in the long-term management of an invasive non-native plant. Understanding what motivates volunteers to join and to stay involved over time is important to improve their experience and to support the recruitment and retention of a voluntary workforce, thus making initiatives cost-effective and rewarding for volunteers and managers alike (Locke, Ellis, and Smith 2003; Bell et al. 2008). Research on environmental volunteerism has explored the diversity and salience of volunteers' motivations and identified which motives underpin initial and sustained engagement. However, less is known about the dynamics of volunteering motivations over the time of one's involvement and over the course of nature restoration initiatives.

The next section describes two different approaches to volunteering motivations; functionalism and process-based models, and examines their use in the context of sustained environmental volunteerism. 


\subsection{Two models of volunteering motivations: Functionalism and process-based approaches}

\subsubsection{Volunteering as a way of fulfilling social and psychological functions}

Volunteering motivations have often been explored from a functionalist perspective.

This approach conceptualises volunteering as a way of fulfilling personal needs and goals, which may differ between volunteers engaged in the same activity (Snyder 1993;

Clary et al. 1998). The Volunteer Functions Inventory (VFI) (Clary et al. 1998) lists six types of functions served by volunteerism: the expression of altruistic values, learning and understanding, social goals, career development, addressing personal problems and negative feelings (“ego protection"), and seeking positive feelings and personal development ("self-enhancement"). Initially elaborated in the context of community and health services, the VFI has been applied and expanded to reflect the specific motives associated with environmental activities such as habitat restoration, litter clean-up, and wildlife monitoring. The most salient motive of engagement in such projects corresponds to the VFI "value expression" function and represents the desire to help wildlife and conserve natural habitats (Ryan, Kaplan, and Grese 2001; Bruyere and Rappe 2007; Measham and Barnett 2008; Asah and Blahna 2012). Volunteers may feel responsible for protecting nature for its own sake or for preserving a legacy for future generations (Warburton and Gooch 2007). Beyond moral imperatives, volunteering may also be motivated by the desire to take meaningful action for nature (Miles, Sullivan, and Kuo, 1998), through hands-on involvement in activities that "make a real difference" (Schroeder 2000, 253). Moreover, while volunteerism may reflect general environmental worldviews, place attachment, or the "emotional bonds" developed towards particular places (Muhar et al., forthcoming), may inform engagement in specific projects (Gooch 2003; Amsden, Stedman, and Kruger 2013; Krasny et al. 
2014).Volunteers, however, do not only wish to help the environment but also to see and be in the natural world (Bruyere and Rappe 2007; Liarakou, Costelou, and Gavrilakis 2011). The experiential dimension of environmental volunteering may be linked to different aspects of the "self-enhancement" and "ego protection" functions of the VFI, including physical exercise, introspection, and escape from the daily routine (Miles, Sullivan, and Kuo 1998; Ryan, Kaplan, and Grese 2001), as well as learning about nature (Lawrence 2010; Hobbs and White 2012; Krasny et al. 2014).

Some functions, such as socialising, self-enhancement, and ego protection, have been found to predict committed and sustained engagement in environmental stewardship activities (Ryan, Kaplan, and Grese 2001; Asah and Blahna 2012, 2013). However, it is less clear how motivational functions evolve during volunteers' participation in conservation initiatives and how changes in the context of a project influence this evolution.

\subsubsection{Volunteering as a process}

While the functionalist perspective focuses specifically on volunteers' personal goals, Penner $(2004,648)$ argues that "a full understanding of sustained volunteering requires a consideration of situational, dispositional, and structural variables and must have a temporal and dynamic component as well". A process-oriented perspective conceptualises volunteering as the product of changing interactions between multiple individual, experiential, and contextual factors. Here, we will explore two particular process-based frameworks: the Model of Sustained Volunteerism (MSV) (Penner 2002) and the Volunteer Process Model (VPM) (Omoto and Snyder 2002).

The MSV and the VPM build on the functionalist perspective and give a central role to personal goals in the initial decision to volunteer. Nonetheless, these models also 
highlight the influence of dispositional and situational factors, such as demographic, social, and cultural variables, on volunteering behaviours. For example, understanding and values of nature, views on environmental governance, and preferred forms of engagement may differ between ethnic and religious groups and be more or less conducive to volunteering in conservation organisations (Kloek et al., forthcoming). Moreover, the two models emphasise the role of organisational attributes (e.g. values, practices, and reputation) in the decision to volunteer. Features of conservation initiatives, such as the perceived professionalism and scientific legitimacy of the organisation (Grimm and Needham 2012), as well as their ecological setting and focus, may inform volunteers' initial involvement. Volunteers may favour activities that allow them to work in close contact with iconic animals (Campbell and Smith 2006), to visit beautiful places, and to see interesting wildlife (Grimm and Needham 2012).

Following the decision to volunteer, dispositional and situational variables continue to influence participants' early involvement, alongside volunteering experiences. Relevant aspects of the latter include volunteers' satisfaction with the activity and relationships with the organisation and other participants. These experiences may in turn lead to changes in volunteers' knowledge, attitudes, motivations, and commitment, more particularly to the development of a "role-identity" (Grube and Piliavin 2000; Piliavin, Grube, and Callero 2002), which supports sustained involvement in the MSV.

Research in environmental volunteerism has often taken a functional perspective, focused on individuals' personal motives and the benefits they gain from the activity. While some goals and rewards have been found to support sustained engagement, we need to better understand how these motives develop over time, as the 
result of a process, which is shaped by multiple individual, social, and biophysical factors, and why these motives are activated in some volunteers but not in others.

\subsection{Focus of the study}

This study combines cross-sectional and longitudinal qualitative research designs and aims to: (a) examine volunteers' motivations at different points over the time of their involvement; (b) investigate how and what experiences change motivations over time; (c) explore the practical implications of the dynamics of motivations in terms of volunteer recruitment and retention; and (d) discuss the strengths and weaknesses of the functional approach and process-based models for understanding changes in motivations in environmental initiatives.

\section{Methods}

\subsection{Tree mallow in the Firth of Forth and the SOS Puffin project}

This study examines the motivations of volunteers in SOS Puffin, a habitat restoration project aiming to address the invasion of tree mallow (Lavatera arborea) on seabird islands of the Firth of Forth in southeast Scotland. Native to the very southwestern tip of the United Kingdom only, tree mallow was introduced in coastal gardens, well outside its native range. From there, it is believed to have spread and established in natural and semi-natural areas (Cox 2002). Since the 1990s, the plant has rapidly expanded on several islands of the Firth of Forth due to the combined effect of climate change, increased soil fertility, and suppressed rabbit grazing caused by a myxomatosis outbreak. The expansion of tree mallow in dense stands up to three meter high, which prevent successful breeding of ground-nesting birds, is believed to have contributed to a steep decline in large colonies of Atlantic puffins (Fratercula arctica) on Craigleith and 
Fidra, two small islands off the coast of North Berwick, about 25 miles from Edinburgh (Van der Wal et al. 2008).

The SOS Puffin initiative was launched in 2007 to address growing concern about the impact of tree mallow on the iconic puffin (Fischer and Van der Wal 2007). This local partnership between volunteers, public organisations, land owners, and scientists aims to restore the puffin breeding habitat and perennial maritime vegetation on Craigleith and supports the management of tree mallow on the nearby islands of Fidra and The Lamb. Volunteer days are organised up to three times a week between late August and April, wind conditions permitting, outside the puffin and grey seal breeding seasons. Volunteers cut tree mallow with shears, loppers, and brush-cutters. The size of the work parties is limited by the capacity of the boats and ten participants on average partake in a work day. Despite these constraints, more than a thousand volunteers have contributed to the management of tree mallow between 2007 and 2015 and the project continues to attract interest.

\subsection{Data collection}

The study draws on a repeated survey with open-ended questions, conducted in 2010 and 2014, and on a set of in-depth interviews with volunteers carried out in 2015.

First, we ran a repeated survey to make cross-sectional and longitudinal observations of volunteers' motivations, views, and perception of change during two phases of the project: (a) a phase of establishment (between 2007 and 2010), characterised by high uncertainty regarding tree mallow management and rapid expansion of the group; and (b) a phase of persistence (between 2010 and 2014), defined by higher level of certainty and slower expansion of the group. The initial questionnaire was designed to collect feedback on volunteers' experience so as to 
inform future management and contained eight open-ended questions: (a) two general questions on motivations to join, stay involved, and leave the project, (b) four questions that specifically prompted respondents to explore some of the factors identified in the literature (see Section 1.2), including the dimensions of the experience that they did and did not enjoy, their perception of the project's aims, and changes in knowledge, attitude and motivation, and (c) two questions inviting respondents to provide further comments and suggestions of improvement. The questionnaire was designed with input from the SOS Puffin leader, who also emailed out the survey in March 2010 to all prospective participants and volunteers listed in the project database by that date $(n=470)$, with a repeat notice sent in early April 2010. 87 questionnaires were returned (response rate $=$ 19\%). An expanded version of this questionnaire, which included additional questions on changes in views and volunteers' social and demographic characteristics, was pilottested and emailed out in late November 2014 to 631 individuals, with a repeat notice sent in early December 2014. This time, 81 questionnaires were returned (response rate $=13 \%) .24$ of these were sent by individuals who had previously taken part in the 2010 survey ("repeat respondents"). Half of the repeat respondents had been largely inactive between the two surveys. Only four had been very active and had attended at least 20 work parties between 2010 and 2014. The repeated measures thus primarily gave an indication of changes occurring as volunteers became inactive or took part very occasionally. Most questionnaires were returned to the authors by email, generally nonanonymously, which allowed the identification of repeat respondents and to link individuals to attendance records collated by the SOS Puffin leader. Seven respondents could not be identified. Even though participants were guaranteed anonymity (i.e. all data was anonymised), the identifiability of the questionnaires may have influenced responses and deterred the expression of more critical comments. Moreover, whereas all 
categories of involvement were represented in the sample (Fig. A1 in Appendix A), first-time participants and inactive volunteers were under-represented in both surveys. This caveat implies that potential sources of dissatisfaction and other reasons for dropping out may not have been captured. Nevertheless, informal conversations between the first author and volunteers who did not take part in the survey tended to align with the results.

Fourteen semi-structured, face-to-face interviews were conducted between September and November 2015 with 18 volunteers (Table A1 in Appendix A). Three of these were run in groups of two to three people (e.g. where the interviewees lived together or were friends). The sampling strategy aimed to maximise diversity in volunteers' level of experience. The interview schedule (Appendix B) was designed to explore in greater depth motivations and processes of change from volunteers' perspective. Photographs of the islands and the work parties at different times of the project were used to prompt interviewees to discuss significant experiences, evoke memories of various aspects of the work parties, and recall changes in the initiative over time.

The study was carried out with the approval of the SOS Puffin Management Group and the authors' institutional Research Ethics Committee (REC references \#31/2014 and \#43/2015). The surveys and interviews were conducted with respondents' informed consent and all data was anonymised.

\subsection{Analysis}

The interviews were digitally recorded and transcribed verbatim. Their duration ranged from 52 minutes to two hours. The interview transcripts and qualitative data from the survey were coded thematically by the first author (Miles and Huberman 1994), with 
the help of the data management software NVivo10. The coding framework was initially built on the survey and interview questions. It included the following concepts: first contact with the project, initial motives, reasons for staying active or becoming inactive, sources of (dis-)satisfaction, most memorable experiences, views on the project's aims, perceived changes, and suggestions for improvement. Text corresponding to each of these concepts was then coded both inductively and deductively, using empirical and theoretical literature on motivational functions and volunteering processes. These codes were finally grouped into categories. Six categories were identified in volunteering motivations: caring for nature, benefits from the activities and nature on the islands, learning and improving career prospects, social motives (in and outside the group), project organisation, and personal circumstances. Some motives that did not fit in these categories (e.g. obligation as part of one's job) were kept separately. From these, three main motivational themes emerged: (a) caring for nature, (b) performing volunteering, and (c) social interactions. Moreover, the repeated survey and data from the repeat respondent subset was coded longitudinally (Saldaña 2009) to track the nature and direction of changes in volunteers' motivations and views, and of changes in the project's context.

In addition to the repeated survey, a time component was incorporated to the analysis in two ways. First, survey respondents and interviewees were categorised into four groups according to their level of experience in the project (Fig. 1). We used the number of work parties attended as the basis for the classification rather than other metrics such as the duration of involvement. We were indeed interested in how volunteers' experiences during the work parties potentially affected motivations. The classification aimed to encapsulate specific phases in the volunteering process and types of behaviour. The first group, "prospective volunteers", represented those who had 
expressed an interest but had not yet taken part in the project. Participating volunteers were divided into three categories: "new volunteers" (1 to 3 work parties attended), who represented $86 \%$ of all participating SOS Puffin volunteers; "returning volunteers" (4 to 14 attendances over a period of time spanning from a few weeks to more than 8 years); and "experienced volunteers" (at least 15 attendances over more than 3 years), who represented only $2 \%$ of the participating SOS Puffin volunteers and were often referred to as the core members of the initiative. Finally, volunteers were classified as inactive if they had not attended a work party for more than a year. Secondly, when possible, motivations, experiences, and changes described in the interviews were assigned a code referring to the period of the project during which they had occurred.

[Figure 1 around here]

We examined changes in motivations over the time of volunteers' involvement, as they evolved from prospective to experienced volunteers or as they became inactive. We compared motivations between categories of experience and between the 2010 and 2014 repeated responses. Volunteers' own account of change in their motives and views were used to triangulate and bring further context to these observations. We also explored changes occurring over the course of the project, from its establishment to the persistence stage, by comparing responses to the 2010 and 2014 surveys and in the repeat respondent subset. Long-term volunteers' recollection of the history of the project was considered, again to support and explain conclusions drawn from the survey.

The next section first discusses the nature of volunteering in SOS Puffin and highlights two factors influencing behaviours, regardless of volunteers' motives. We then explore motivations and changes over the time of individual volunteers' 
involvement across the three main themes that emerged from the data. Finally, we examine how motivations in the group evolved over the course of the initiative.

\section{Results}

\subsection{Volunteering in SOS Puffin: A process shaped by personal circumstances and external barriers}

Attendance records and data from the survey and interviews showed that involvement in SOS Puffin was for the majority of the volunteers short-term or intermittent. While most participants dropped out at the new volunteer stage, often after attending their first work party, respondents at all levels of involvement expressed overwhelmingly positive views on their experience in the project and the survey and interviews indicated that dropout was rarely caused by dissatisfaction.

Inactivity at the new and returning volunteer stages largely resulted from (changing) personal circumstances, most notably conflicting family and work commitments, difficulties with transport arrangements, and health issues (Table 1). Conversely, experienced volunteers' engagement appeared mainly hindered by external barriers, particularly work parties being cancelled due to adverse weather or to the unavailability of a ship.

The volunteering process did not necessarily cease as volunteers became inactive. Many former participants remained generally interested in the fate of the islands and the initiative. Repeated responses to the two surveys revealed that people continued to think about SOS Puffin, even during periods of inactivity, and that their attitudes could change positively as they followed the project's regular updates. Some inactive members simply felt less needed or had lost the habit of taking part. Others hoped to join again when personal circumstances permitted. 
Engagement in SOS Puffin was thus largely influenced by personal circumstances and external barriers, which significantly shaped volunteering behaviours regardless of participants' motivations. However, the extraordinary nature of the experience on the seabird islands also supported motives that were less conducive to long-term and regular involvement, as will be explored in the next section, which focuses on motivations and their evolution over the time of volunteers' engagement.

[Table 1 around here]

\subsection{Dynamics in motivations, perceptions, and relationships over the time of volunteers' involvement}

Three main motivational themes were found to inform volunteering at all levels of experience, although their focus could change over the time of one's involvement (Table 1).

\subsubsection{Caring for nature and wildlife: From value expression to an attachment to places}

Volunteers' desire to help the birds and nature were the most common reasons for taking part in SOS Puffin. These motives were often underpinned by moral values, expressed as the need to give back to nature, to preserve puffin colonies for future generations, and to take responsibility for the introduction of tree mallow and what was considered to be human-made damage. Instrumental values of the puffins, most notably people's enjoyment of these attractive birds and their importance to the local wildlife tourism industry, also justified tree mallow management and motivated personal engagement. Above all, however, the majority of the volunteers referred to their engagement in SOS Puffin (and other conservation initiatives) as a manifestation of their love for nature, of a passion for puffins, birds, and natural history, and of a 
particular affinity for the coastal environment or the local area. In the interviews, volunteers often traced back their interest and affection for nature and wildlife to childhood experiences of the outdoors, formal and informal education, and prior visits on seabird islands.

Although some form of attachment to the area and species was therefore often at play initially, some respondents (including new participants) reported in the surveys and the interviews that their love for and commitment to nature had been renewed in contact with the environment of the islands and that their specific concern for the fate of Craigleith and Fidra had grown after visiting the places and learning more about them. Standing in the shadow of more renowned local seabird sanctuaries, such as the Isle of May and the Bass Rock, these smaller islands appeared bigger, more biodiverse, and more interesting and ecologically significant than volunteers had initially imagined. Furthermore, observing the impact of tree mallow on puffin burrows invited volunteers to empathise more strongly with the birds. In contrast, the rapid and persistent regeneration of the plant could fuel greater dislike towards tree mallow, reinforcing the perception of contributing to a worthwhile cause and inspiring "sheer bloody mindedness and determination to eradicate [tree mallow] once and for all!", as stated by an experienced volunteer in the 2010 survey.

Over time, some volunteers developed stronger personal attachment to Craigleith and Fidra. Some took pride in visiting the islands for a purpose and in having privileged access and knowledge of the places:

Interviewer: In what sense does [visiting the islands for a purpose] make a difference to you?

Christine: Well I know I've taken pride. [...] You just feel you know the islands so much better $[\ldots]$ because we've been on them so many times. You just feel like you know these islands and a lot of other people don't. 
It's not one-upmanship, it's really just that you've been there so, you know, it's the knowledge of the islands.

Duncan: There is a wee bit of one-upmanship as far as I'm concerned. [...]. We are getting on a boat in the harbour and we're putting on our things and there are people watching us. And when we come back in, there's people watching us.

The development of intimate knowledge of the islands over the time of one's involvement led to a sense of ownership and protectiveness:

You become more possessive, it's an island I know - not a case of saying 'it's my island' but it's an island you know more about now and you wouldn't like to see somebody else going out there and doing something silly without knowing why, 'What are they doing on our island?' (Tom, experienced volunteer)

An experienced member described the life-changing impacts of his involvement in SOS Puffin and connected such transformative experiences to the islands, which stood as representations and reminders of his personal journey and of his new role in the protection and promotion of the environment of the Firth of Forth:

[The islands] have become so special and symbolic almost to the very reason I went out there and this cornerstone of all that has come after that, so they are very special to me. (Andy, experienced volunteer)

Overall, thus, volunteers' motivations related to the conservation cause as such appeared to develop from relatively clear and focused notions of giving something back to nature and helping a charismatic species, to complex conglomerates of emotional and cognitive motivations. These environmental motives rested on increasingly profound and holistic, albeit potentially ambivalent, attachments to wildlife and places. As we will see in the following section, these were closely intertwined with motivations that tapped into the experiential dimensions of conservation volunteering. 


\subsubsection{Performing volunteering: From the enjoyment of short-term rewards to long-term challenges and new opportunities for learning and participation}

Motivations at all stages of involvement strongly related to actually performing a practical activity in the outdoors. Prospective volunteers hoped to enjoy the natural environment and the work, to get some fresh air and exercise, to experience an adventurous day out, and to make a real difference by helping the puffins in a practical way. Some of these expectations built on prior positive experiences in other environmental volunteering projects and on the specific appeal of going by boat to special places that are normally inaccessible to the public.

Four aspects of the visits were particularly memorable: the sense of immersion in the natural world from being surrounded by the sea and experiencing nature with all the senses; the beauty of the islands and the views; the sense of adventure (being stranded on a small island, getting on and off the boat, and the challenging terrain); and the novel and exclusive nature of the experience (access, observing wildlife up close in their natural habitat, and seeing North Berwick from a new perspective). The experience often evoked intense emotions of wonder, privilege and excitement, alongside peacefulness and a sense of connectedness with nature, expressed as the feeling of "being among it all".

Cutting tree mallow fulfilled different motivational functions, including helping nature in a practical way, physical exercise and challenge, and introspection. The majority of the respondents enjoyed the activity itself, despite differences in preferred terrain and task. Most enjoyed removing the larger plants because the activity was less uncomfortable, progressed faster, and felt more involving. The resistance of the plant and the "crunch" as the stalk was cut were most satisfying. Other volunteers preferred to "tidy up" the smaller seedlings. Some sought the challenge of climbing steep cliffs and 
"getting to the hard to reach places", while others were keener to work on flatter areas because they did not deal as well with heights. Preferences regarding the activity also mobilised norms defining what a good volunteer should do (e.g. serious volunteers should work hard).

Furthermore, the sense of achievement from cutting the plant and seeing progress was particularly gratifying. First, the task required limited skills and strength and, accordingly, allowed volunteers of all abilities to contribute to the work of the group and to feel useful. Secondly, the results were immediately apparent: one could see the cleared areas and tree mallow piled up at the end of the day. Significantly, in contrast to other activities such as fence building or litter picking, clearing the puffin burrows evoked a direct and personal connection between the work of the volunteers and the nesting success of the birds:

You are making a genuine difference by what you personally do in the day on the basis that puffins try and go back to the same burrow. It's very personal. Whereas with [cutting] sea buckthorn [on another local nature reserve], it's just a huge area, so you don't feel as if it's that personal. [...] You feel as though you are helping individual birds. For whom that is their home, their habitat. (Ed, returning volunteer)

Performing volunteering thus entailed three motivational dimensions: the enjoyment derived from aesthetic and novel experiences of nature on the islands and from the work itself; the sense of purpose from being actively involved in a project that made a difference; and the physical and intellectual challenge and learning experience. Importantly, these three aspects could evolve over time. The novelty of the visits and of the work played a significant role in early volunteering, as a source of excitement and anticipation (and more negatively, as a factor of apprehension), but the activity and its setting could become more mundane over time. Some returning and experienced 
volunteers appreciated the occasional nature of the visits or argued that the unpredictability of the environment and the turn-over of volunteers made every trip feel different. However, one needed to consciously reflect on the special nature of the experience:

There's a combination of the reassuring 'you know what's going to happen' but also the kind of you don't know who you are going to meet and you don't know what the weather is going to be like. Every now and again just stopping and looking at the view and reminding yourself how beautiful it is, things like that. (Vicky, experienced volunteer)

As the salience of motivations linked to the enjoyment of the experience lessened over time, new opportunities for learning and participation could become more important drivers:

I've still got all of that original passion to get out there and give something back $[\ldots]$ - whereas that was the original driver, that's very much the foundation now $[\ldots]$. The new driver is all of this new stuff I've learned and all the new opportunity [...]. I'm now giving back to people who don't know the first thing about seabirds just like I did ten years ago and it's great to see them so enthusiastic. (Andy, experienced volunteer)

Moreover, while volunteers enjoyed the immediate rewards of cutting tree mallow, the long-term and more indirect impacts of the project raised concern overall. New participants were shocked by the size of the task and this initial surprise developed into emotional ups and downs, as volunteers became personally invested in the initiative:

You can land and suddenly see this in front of you, 'oh my goodness, it's all come back again'. [...]. Depending on the time of year, you might land and say, 'God, where's all the tree mallow gone? There's nothing to see. 'It's been cut, the rabbits have eaten it, the winter weather has dealt with it - we're getting somewhere. It's a bit of a roller coaster. (Tom, experienced volunteer) 
One's sense of purpose in the project could thus evolve from short-term achievements to the challenge of sustaining the momentum of the initiative, committing to the work, and seeing the project through. Furthermore, as volunteers became increasingly aware of the complexity of tree mallow management, greater importance was given to the organisation of the initiative, particularly to the role of scientific advice and monitoring in the project governance and opportunities to get access to information about its objectives and achievements.

SOS Puffin participants sought enjoyment, sense of purpose, and understanding of the natural world in performing volunteering activities. The latter goal could gain in significance as volunteers became more interested in the fate of the islands and grew increasingly aware of the uncertainties and complexities associated with the management of tree mallow. Although such motivations largely emerged from direct experiences with the biophysical environment on the islands, volunteers' accounts also revealed the importance of social interactions and the development of relationships with the group in long-term commitment.

\subsubsection{Social interactions: From caring for nature to caring for the group}

Few volunteers initially sought to meet other people through SOS Puffin, yet many grew to enjoy the camaraderie of the group and the opportunity to meet people from all walks of life and to learn from them about the (natural) history of the islands.

Relationships between members usually took the form of a sense of belongingness to a group of like-minded people, which dissolved outside the work parties and ceased entirely as one became inactive. However, this form of social bonding reinforced one's positive attitude and commitment to the project and conservation: 
It's nice to see that there's other people who are as committed to the project and keep coming back. [...] It's just kind of reassuring that you're not mad for doing it, because a few people are sort of 'Why are you doing that? Why are you going all the way over there to work hard all day and hurt yourself and you're not going to get paid?' And I think it's just sort of reassuring that actually this is worth doing. (Alan, new volunteer)

From the very first work parties, volunteers came to appreciate the commitment of the long-term participants and of the group leader, who played a crucial role in the continuity of the project, which was characterised overall by loose membership and high turn-over. Admiration for the core group and leadership evolved into new collectively oriented motivations, namely a sense of loyalty to and responsibility for the project and its participants. Moral duty to the group and its leader constituted strong motivations of on-going engagement in times of adversity and supported participants' decision to take on greater and relatively stressful responsibilities such as leading work parties.

Membership was perceived differently among volunteers. New participants tended to position themselves at the periphery of the initiative, while returning volunteers could identify with an intermediary role of occasional yet serious helpers, situated between casual participants and members of the core group. Some returning volunteers felt that their commitment and experience were at times not sufficiently recognised by the organisation and hoped to get involved in more demanding activities and in the day-to-day management of the project.

Motivations thus evolved from identifiable personal aspirations to more complex assemblages of cognitive, experiential, and social drivers, which involved interplays between volunteers' personal circumstances and goals and attributes of the organisational, social, and biophysical background. In the next section, we focus on the 
social-ecological context of SOS Puffin and explore how changes in the group and the natural environment on the islands influenced the dynamics of volunteering motivations over the time of the initiative.

\subsection{Changes over the time of the project: From initial uncertainties to long- term sustainability}

The 2010 and 2014 surveys, including the repeated measures, revealed that volunteers' motivations had remained largely similar between the establishment and persistence phases of SOS Puffin. In recent years however, external barriers had made participation increasingly difficult. Fewer days were required to complete the annual cut of tree mallow and many of these work parties ended up being cancelled due to adverse weather.

Moreover, participants' perception of progress had changed over the time of the project. While the first phase was characterised by a mix of hope, scepticism, and frustration and the widespread impression that the project had taken much longer than expected, perceptions of more radical and sustained changes in the vegetation of Craigleith justified more optimistic views in the recent survey and interviews. Although encouraging, these changes had weakened the sense of purpose motivating some of the returning and experienced participants. These volunteers felt less needed but also increasingly dissatisfied with the activity itself: "Next time if we cut down ones that are a few inches then I'm not going!" announced a returning volunteer. New volunteers commenting on pictures of changes in the vegetation of Craigleith over the time of the initiative also expressed the sentiment of having "missed out" on the opportunity to truly help.

SOS Puffin had therefore transitioned from a period of high uncertainty regarding the effect of cutting tree mallow to a time when longstanding sustainability 
appeared more at risk. The perception of an immediate threat was softened by the ongoing popularity of the project, yet new challenges associated with leadership succession, long-term governance, and the need to attract younger generations of volunteers were emerging.

\section{Discussion}

\subsection{Motivations and changes}

Penner (2002) defines volunteering as a long-term behaviour but this was not the case for most participants in SOS Puffin. The project exemplified a contemporary style of volunteering, contingent on personal circumstances and focused on active selfrealisation and on the fulfilment of individual goals (Hustinx and Lammertyn 2003). Our findings confirm the range and diversity of volunteering motives identified in other conservation initiatives (see Section 1), notably a concern for the environment and the desire to help in a practical way, be in and learn about nature, and meet other people. Nevertheless, the unusual setting of SOS Puffin shed light on motives that may have been neglected in previous studies based on the Volunteer Functions Inventory, namely the opportunity to access places or to do something privileged, and to share knowledge with others.

We found that volunteers' personal goals and circumstances and the focus of the project were the main factors influencing people's initial decision to take part but that other variables of the Model of Sustained Volunteerism (MSV) and the Volunteer Process Model (VPM), such as social pressure and organisational attributes, were initially less prominent. Personal motives, positive experiences, and growing commitment to the project continued to motivate involvement in early and sustained phases of engagement, in alignment with the two models. The MSV emphasises the 
significance of role-identity in motivating long-term engagement of volunteers. It was difficult to identify this concept in our data but somewhat easier to detect when volunteers had not developed a role-identity as SOS Puffin members. For example, some respondents indicated that they did not think much about the project outside the work parties or did not consider themselves as members of the initiative. It is reasonable to assume that very few participants indeed felt strongly about being a volunteer in SOS Puffin because participation often remained merely occasional, even among some of the most experienced volunteers. It appears however that a general role-identity as an environmental volunteer could play a part in participants' initial and sustained motivations. Many respondents indicated being involved in the project as part of a wider set of environmental volunteering roles. Place attachment as an element of one's identity (Stedman 2002) may also represent a relevant concept to think about roleidentity in the case of SOS Puffin. We found that volunteers' relationship with the islands changed over time. They developed greater appreciation and, in some cases, a more personal attachment to the places, as sites that they were proud to know intimately and to help preserve and that were important to their own identity. Most volunteers thus did not seem to develop a SOS Puffin volunteer role-identity, yet some more clearly identified with a role of stewards of the islands and the Firth of Forth. Finally, the role of habit, which is not explicitly present in the MSV and the VPM, should be highlighted. Although volunteering remained a reflexive activity, taking part in SOS Puffin as part of a regular hobby and being out of the habit of attending work parties influenced active and inactive volunteers, respectively.

Importantly, while personal motives based on moral values of nature and the desire to "do their bit" for puffins persisted after repeated visits, other drivers that were initially important, such as the enjoyment of novel and aesthetic experiences on the 
islands, could become less significant over time. Instead, such experiences could foster or renew participants' fascination with the natural world and interest in learning more about the islands, the birds, and the management of tree mallow. Moreover, new motives, in which self-fulfilment and moral responsibility were intertwined, emerged from developing attachments to the islands and the group. Volunteers took pride in playing a role in the management of special places with a group of like-minded people but were also increasingly motivated by collectively oriented motives grounded on loyalty and a sense of duty to the project and other participants, which could sustain motivation in spite of monotony and frustration. In the social care sector, Cloke, Johnsen, and May (2007) similarly found that volunteering could become entrenched in complex negotiations between the self-fulfilling camaraderie derived from loyalty to the group and their selfless engagement in emotionally challenging activities. Our results therefore suggest that hedonic motives (e.g. the pleasure of being in a beautiful place) may encourage initial engagement in environmental volunteering but that moral concerns and eudemonic drivers pertaining to people's connectedness to nature, social bonding, and quest for meaningfulness and learning support sustained committed action (see van den Born et al., forthcoming).

\subsection{Theoretical and methodological implications}

Our findings highlight the joint influence of situational variables and of social-culturally embedded concepts of nature on environmental behaviours (see Muhar et al., forthcoming).Volunteers' life history and circumstances encouraged or not the expression of environmental values. In a similar way, initial and on-going motives such as "making a real difference" for nature were often inherently associated with specific attributes of the project: the focus of the initiative on the protection of an iconic bird in 
its natural habitat; the low level of technicality of the work; the role of the burrows in physically connecting the work of the volunteers and the life of the puffins; and the perception of contributing to a worthwhile project that is science-based and professionally led. By decontextualising volunteering motivations, functional approaches may fail to recognise situation-specific drivers that may not apply to other initiatives and individuals or may change over the course of a project and of one's involvement.

Multivariable models, such as the MSV and the VPM, recognise the interplay between situational factors and motives. However, these models, which were developed in the domain of social services, focus on volunteers' experiences with the organisation and its members but do not consider interactions with the biophysical context (see Muhar et al., forthcoming). Participants' accounts of their experiences in SOS Puffin emphasised the performative nature of environmental volunteering. In cutting tree mallow, volunteers sought to fulfil different functions, such as helping the puffins to access their burrows, getting fit, or escaping their troubles. However, the enjoyment of cutting tree mallow did not only depend on the strength of these personal goals. It involved volunteers' physical capacity, their ability to use the tools, and their perception of discomfort and efficacy, and also, importantly, biophysical, technological, and social entities: tree mallow, the terrain, the shears and loppers, the co-workers, and what it meant to be a (good) volunteer. We see here the interest in conceptualising volunteering motivations as co-productions between human, non-human, physical, and symbolic entities that populate the volunteering experience, rather than as psychological needs and goals held by volunteers only. The concept of "embodied ecosystems", i.e. "web[s] of embodied relations that exist between humans and environment" (Raymond, Giusti, and Barthel, forthcoming) could be a particularly fruitful addition to the set of existing 
models of volunteering motivations presented in this paper. Considering volunteering sites as embodied ecosystems could help improve understanding of how volunteering experiences and the organisational, social, biophysical, and individual context through which they take place, produce volunteering benefits. This approach would consider motivations as emergent rather than pre-existing, relatively static, psychological goals, and may thus be better equipped than functional approaches in dealing with the dynamic nature of motivations or than process models such as the VPM, which artificially distinguish volunteering antecedents, experiences, and changes, while the three stages may be better understood as occurring simultaneously.

Finally, the study highlights the shifting nature of volunteering motivations. Over the time of their involvement, volunteers were motivated by the personal benefits they gained from the experience but the nature of such rewards could change (e.g. from visiting a new place to being proud of knowing it) and increasingly emerged from forms of attachment to the islands and the group. This suggests that functional approaches may be more suited to the investigation of motivations at the onset of one's involvement but that models such as the MSV and the VPM, that integrate factors relating to volunteers' relationships with a project, are needed to understand on-going involvement (see also Chacón, Vecina, and Dávila 2007). Moreover, shifting the focus of investigations from the antecedents of volunteering (e.g. functions) to the characteristics of volunteering experiences that lead to enduring motivations, such as role-identity or, in our study case, place and group attachment, may be an interesting avenue to inform volunteering programmes that are satisfying and foster desirables changes in humannature relationships. Qualitative phenomenological approaches such as life narratives (Chawla 1999; van den Born et al., forthcoming) may be particularly useful to identify significant experiences such as environmental epiphanies (Vining and Merrick 2012) 
and social groups and figures (e.g. family, mentors) that are important in the formation of on-going volunteering motivations.

\subsection{Practical implications: Alleviating personal barriers and promoting collective identity and place attachment}

Managers who wish to retain volunteers in the long-term should attempt to alleviate personal barriers to engagement, for example by ensuring that the physicality of the work, timing, and transport arrangements suit the volunteers they seek to involve.

Moreover, they need to provide experiences that foster the development of social bonding and/or connectedness to nature and attachment to places. Leadership was an important factor in the formation of attachments to the project in SOS Puffin. Conveying a clear vision and encouraging discussions facilitated the formation of shared objectives and values. The presence of a stable figure at the head of the initiative also helped to bring coherence and continuity to the collective work of hundreds of temporary participants. Regarding the development of an attachment to natural sites and wildlife, project managers can cultivate volunteers' curiosity by providing affective experiences that stimulate their sense of empathy, awe, wonder, and privilege (Curtin and Kragh 2014). The interplay between memorable experiences of nature and social interactions (e.g. sharing and discussing the experience with others) can lead to increased interest in and emotional connectedness to the natural world and, as a result, to raised awareness, concern, and willingness to act for the environment and wildlife (Curtin and Kragh 2014). Factors that made experiences of nature memorable in SOS Puffin included proximity of and interactions with wildlife and their habitat, isolation and immersion in nature, seeing things for the first time and encountering charismatic species (see also Curtin 2010; Ballantyne, Packer, and Sutherland 2011). 


\section{Conclusion}

Functionalist approaches have commonly been used to investigate volunteering motivations, and have recently been expanded to accommodate the specific reasons underlying people's engagement in habitat restoration and other conservation activities. Although the concept of motivational functions can be useful in identifying volunteers' initial expectations and needs, it is less helpful in capturing the complex and shifting social, organisational, and environmental attachments and multi-faceted experiences that motivate volunteers' on-going involvement. Considering volunteering motivations as co-produced by human and non-human entities in the volunteering space rather than as pre-existing psychological needs, may improve our understanding of the dynamics of motivations and hence of long-term volunteering.

\section{Acknowledgements}

The authors thank the SOS Puffin volunteers and the Craigleith Management Group for their support in this research project. We also thank John Hunt (SOS Puffin), Anja Byg and Kerry Waylen (The James Hutton Institute), Norman Dandy (Plunkett Foundation), Michelle Pinard (University of Aberdeen), and four anonymous reviewers for their valuable comments on earlier versions of this paper. We acknowledge funding by the Natural Environment Research Council and the Rivers and Fisheries Trust of Scotland (Award 1299449).

\section{References}

Amsden, B., R. C. Stedman, and L. E. Kruger. 2013. "Volunteer Meanings in the Making of Place." In Place-Based Conservation: Perspective from the Social Sciences, edited by W. P. Stewart, D. R. Williams, and L. E. Kruger, 109-118. Dordrecht, NL: Springer. doi:10.1007/978-94-007-5802-5_9. 
Asah, S. T., and D. J. Blahna. 2012. "Motivational Functionalism and Urban Conservation Stewardship: Implications for Volunteer Involvement.” Conservation Letters 5 (6): 470-477. doi:10.1111/j.1755-263X.2012.00263.x.

Asah, S. T., and D. J. Blahna. 2013. "Practical Implications of Understanding the Influence of Motivations on Commitment to Voluntary Urban Conservation Stewardship." Conservation Biology 27 (4): 866-875. doi:10.1111/cobi.12058

Ballantyne, R., J. Packer, and L. A. Sutherland. 2011. "Visitors' Memories of Wildlife Tourism: Implications for the Design of Powerful Interpretive Experiences." Tourism Management 32 (4): 770-779. doi:10.1016/j.tourman.2010.06.012. Bell, S., M. Marzano, J. Cent, H. Kobierska, D. Podjed, D. Vandzinskaite, H. Reinert, A. Armaitiene, M. Grodzińska-Jurczak, and R. Muršič. 2008. "What Counts? Volunteers and their Organisations in the Recording and Monitoring of Biodiversity." Biodiversity Conservation 17 (14): 3443-3454. doi:10.1007/s10531-008-9357-9.

Bruyere, B., and S. Rappe. 2007. "Identifying the Motivations of Environmental Volunteers.” Journal of Environmental Planning and Management 50 (4): 503516. doi:10.1080/09640560701402034.

Bryce, R., M. K. Oliver, L. Davies, H. Gray, J. Urquhart, and X. Lambin. 2011.

"Turning Back the Tide of American Mink Invasion at an Unprecedented Scale through Community Participation and Adaptive Management." Biological Conservation 144 (1): 575-583. doi:10.1016/j.biocon.2010.10.013.

Campbell, L. M., and C. Smith. 2006. "What Makes Them Pay? Values of Volunteer Tourists Working for Sea Turtle Conservation.” Environmental Management 38 (1): 84-98. doi:10.1007/s00267-005-0188-0.

Chacón, F., M. L. Vecina, and M. C. Dávila. 2007. “The Three-Stage Model of Volunteers' Duration of Service.” Social Behavior and Personality 35 (5): 627642. doi:10.2224/sbp.2007.35.5.627.

Chawla, L. 1999. "Life Paths into Effective Environmental Action." The Journal of Environmental Education 31 (1): 15-26. doi:10.1080/00958969909598628.

Clary, E. G., M. Snyder, R. D. Ridge, J. Copeland, A. A. Stukas, J. Haugen, and P. Miene. 1998. "Understanding and Assessing the Motivations of Volunteers: A Functional Approach.” Journal of Personality and Social Psychology 74 (6): 1516-1530. doi:10.1037/0022-3514.74.6.1516. 
Cloke, P., S. Johnsen, and J. May. 2007. "Ethical Citizenship? Volunteers and the Ethics of Providing Services for Homeless People.” Geoforum 38 (6): 10891101. doi:10.1016/j.geoforum.2006.07.005.

Conrad, C. C., and K. G. Hilchey. 2011. “A Review of Citizen Science and Community-Based Environmental Monitoring: Issues and Opportunities.” Environmental Monitoring and Assessment 176 (1): 273-291. doi:10.1007/s10661-010-1582-5.

Convention on Biological Diversity. 2002. Decision VI/23. Alien species that threaten ecosystems, habitats or species to which are annexed the Guiding principles for the prevention, introduction and mitigation of impacts of alien species that threaten ecosystems, habitats or species. COPVI, The Hague, the Netherlands.

Cox, J. H. S. 2002. "Lavatera arborea Tree Mallow." In New Atlas of the British and Irish Flora, edited by C. D. Preston, D. A. Pearman, and T. D. Dines, 219. Oxford: Oxford University Press.

Crall, A. W., G. J. Newman, T. J. Stohlgren, K. A. Holfelder, J. Graham, and D. M. Waller. 2011. “Assessing Citizen Science Data Quality: An Invasive Species Case Study". Conservation Letters 4: 433-442. doi:10.1111/j.1755263X.2011.00196.x.

Curtin, S. 2010. "What Makes for Memorable Wildlife Encounters? Revelations from 'Serious' Wildlife Tourists.” Journal of Ecotourism 9 (2): 149-168. doi:10.1080/14724040903071969.

Curtin, S., and G. Kragh. 2014. "Wildlife Tourism: Reconnecting People with Nature." Human Dimensions of Wildlife 19 (6): 545-554. doi:10.1080/10871209.2014.921957.

Fischer, A., and R. van der Wal. 2007. "Invasive Plant Suppresses Charismatic Seabird: The Construction of Attitudes towards Biodiversity Management Options." Biological Conservation 135 (2): 256-267. doi:10.1016/j.biocon.2006.10.026.

Ford-Thompson, A. E. S., C. Snell, G. Saunders, and P. C. L. White. 2012. "Stakeholder Participation in Management of Invasive Vertebrates." Conservation Biology 26 (2): 345-356. doi:10.1111/j.1523-1739.2011.01819.x.

Gooch, M. 2003. "A Sense of Place: Ecological Identity as a Driver for Catchment Volunteering." Australian Journal on Volunteering 8 (2): 23-33. 
Grimm, K. E., and M. D. Needham. 2012. "Moving Beyond the 'I' in Motivation: Attributes and Perceptions of Conservation Volunteer Tourists." Journal of Travel Research 51 (4): 488-501. doi:10.1177/0047287511418367.

Grube, J. A., and J. A. Piliavin. 2000. "Role Identity, Organizational Experiences, and Volunteer Performance.” Personality and Social Psychology Bulletin 26 (9): 1108-1119. doi:10.1177/01461672002611007.

Hobbs, S. J., and P. C. L. White. 2012. "Motivations and Barriers in Relation to Community Participation in Biodiversity Recording." Journal for Nature Conservation 20 (6): 364-373. doi:10.1016/j.jnc.2012.08.002.

Hustinx, L., and F. Lammertyn. 2003. "Collective and Reflexive Styles of Volunteering: A Sociological Modernization Perspective.”Voluntas 14 (2): 167-187. doi:10.1023/A:1023948027200.

Kloek, M., A. Buijs, J. Boersema, and M. Schouten. Forthcoming. "Cultural Echoes in Dutch Immigrants' and Non-Immigrants' Understandings and Values of Nature." Journal of Environmental Planning and Management. doi:10.1080/09640568.2017.1319803.

Krasny, M. E., S. R. Crestol, K. G. Tidball, and R. C. Stedman. 2014. "New York City's Oyster Gardeners: Memories and Meanings as Motivations for Volunteer Environmental Stewardship.” Landscape and Urban Planning 132: 16-25. doi:10.1016/j.landurbplan.2014.08.003.

Lawrence, A. 2010. “The Personal and Political of Volunteers' Data: Towards a National Biodiversity Database for the UK.” In Taking Stock of Nature: Participatory Biodiversity Assessment for Policy, Planning and Practice, edited by A. Lawrence, 252-265. Cambridge: Cambridge University Press.

Liarakou, G., E. Kostelou, and C. Gavrilakis. 2011. "Environmental Volunteers: Factors Influencing their Involvement in Environmental Action". Environmental Education Research 17 (5): 651-673. doi:10.1080/13504622.2011.572159.

Locke, M., A. Ellis, and J. Davis Smith. 2003. "Hold On to What You've Got: The Volunteer Retention Literature." Voluntary Action 5 (3): 81-99.

Lorimer, J. 2010. “International Conservation 'Volunteering' and the Geographies of Global Environmental Citizenship." Political Geography 29 (6): 311-322. doi:10.1016/j.polgeo.2010.06.004. 
Measham, T. G., and G. B. Barnett. 2008. "Environmental Volunteering: Motivations, Modes and Outcomes." Australian Geographer 39 (4): 537-552. doi:10.1080/00049180802419237.

Miles, M. B., and A. M. Huberman. 1994. Qualitative Data Analysis: An Expanded Sourcebook. 2nd Ed. Thousand Oaks, CA: Sage Publications.

Miles, I., W. C. Sullivan, and F. E. Kuo. 1998. "Ecological Restoration Volunteers: The Benefits of Participation." Urban Ecosystems 2 (1): 27-41. doi:10.1023/A:1009501515335.

Millennium Ecosystem Assessment. 2005. Ecosystems and human well-being: Current state and trends. Washington, DC: Island Press.

Muhar, A., C. M. Raymond, R. van den Born, N. Bauer, K. Böck, M. Braito, A. Buijs, C. Flint, W. de Groot, C. Ives, T. Mitrofanenko, T. Plieninger, C. Tucker, and C. van Riper. Forthcoming. "Review Paper: A Model Integrating Social-Cultural Concepts of Nature into Frameworks of Interaction between Social and Natural Systems." Journal of Environmental Planning and Management.

Omoto, A. M., and M. Snyder. 2002. "Considerations of Community: The Context and Process of Volunteerism.” American Behavioral Scientist 45 (5): 846-867. doi:10.1177/0002764202045005007.

Penner, L. A. 2002. "Dispositional and Organizational Influences on Sustained Volunteerism: An Interactionist Perspective.” Journal of Social Issues 58 (3): 447-467. doi:10.1111/1540-4560.00270.

Penner, L. A. 2004. "Volunteerism and Social Problems: Making Things Better or Worse?” Journal of Social Issues 60 (3): 645-666. doi:10.1111/j.00224537.2004.00377.x.

Piliavin, J. A., J. A. Grube, and P. L. Callero. 2002. "Role as Resource for Action in Public Service.” Journal of Social Issues 58 (3): 469-485. doi:10.1111/00224537.t01-1-00027.

Raymond, C. M., M. Giusti, and S. Barthel. Forthcoming. "Review Paper: An Embodied Perspective on the Co-Production of Cultural Ecosystem Services: Toward Embodied Ecosystems." Journal of Environmental Planning and Management. doi:10.1080/09640568.2017.1312300. 
Ryan, R. L., R. Kaplan, and R. E. Grese. 2001. "Predicting Volunteer Commitment in Environmental Stewardship Programmes.” Journal of Environmental Planning and Management 44 (5): 629-648. doi:10.1080/09640560120079948.

Saldaña, J. 2009. The Coding Manual for Qualitative Researchers. 1st ed. Thousand Oaks, CA: Sage Publications.

Schroeder, H. W. 2000. “The Restoration Experience: Volunteers' Motives, Values, and Concepts of Nature.” In Restoring Nature: Perspectives from the Social Sciences and Humanities, edited by P. H. Gobster and R. B. Hull, 247-264. Washington, DC: Island Press.

Simberloff, D., J. L. Martin, P. Genovesi, V. Maris, D. A. Wardle, J. Aronson, F. Courchamp, B. Galil, E. García-Berthou, M. Pascal, P. Pyšek, R. Sousa, E. Tabacchi, and M. Vilà. 2013. "Impacts of Biological Invasions: What's What and the Way Forward." Trends in Ecology and Evolution 28 (1): 58-66. doi:10.1016/j.tree.2012.07.013.

Snyder, M. 1993. "Basic Research and Practical Problems: The Promise of a 'Functional' Personality and Social Psychology." Personality and Social Psychology Bulletin 19 (3): 251-264. doi:10.1177/0146167293193001.

Stedman, R. C. 2002. “Toward a Social Psychology of Place: Predicting Behavior from Place-Based Cognitions, Attitude, and Identity." Environment and Behavior 34 (5): 561-581. doi:10.1177/0013916502034005001.

Tulloch, A. I. T., H. P. Possingham, L. N. Joseph, J. Szabo, and T. G. Martin. 2013. "Realising the Full Potential of Citizen Science Monitoring Programs." Biological Conservation 165: 128-138. doi:10.1016/j.biocon.2013.05.025. Van den Born, R., B. Arts, J. Admiraal, A. Beringer, P. Knights, E. Molinario, K. Polajnar Horvat, C. Porras-Gomez, A. Smrekar, N. Soethe, J. L. Vivero-Pol, W. Ganzevoort, M. Bonaiuto, L. Knippenberg, and W. de Groot. Forthcoming. "The Missing Pillar: Eudemonic Values in the Justification of Nature Conservation.” Journal of Environmental Planning and Management.

Van der Wal, R., A.-M. Truscott, I. S. K. Pearce, L. Cole, M. P. Harris, and S. Wanless. 2008. "Multiple Anthropogenic Changes Cause Biodiversity Loss through Plant Invasion." Global Change Biology 14 (6): 1428-1436. doi:10.1111/j.13652486.2008.01576.x. 
Vining, J., and M. S. Merrick. 2012. "Environmental Epiphanies: Theoretical Foundations and Practical Applications." In The Oxford Handbook of Environmental and Conservation Psychology, edited by S. D. Clayton, 485-508. New York: Oxford University Press. doi:10.1093/oxfordhb/9780199733026.013.0026.

Warburton, J., and M. Gooch. 2007. "Stewardship volunteering by older Australians: The generative response." Local Environment 12 (1): 43-55. doi:10.1080/13549830601098230. 
Appendix A. Characteristics of the survey and interview samples

[Figure A1 here] 
Table A1. Characteristics of the interview respondents

\begin{tabular}{|c|c|c|c|c|c|c|}
\hline Name & $\begin{array}{c}\text { Level of } \\
\text { experience }\end{array}$ & $\begin{array}{c}\text { Duration of } \\
\text { involvement } \\
\text { (in years) }\end{array}$ & $\begin{array}{l}\text { Activity in } \\
\text { the year } \\
\text { preceding } \\
\text { the } \\
\text { interview }\end{array}$ & $\begin{array}{l}\text { Period of } \\
\text { initial } \\
\text { involvement }\end{array}$ & Age & $\begin{array}{c}\text { Type of } \\
\text { interview }\end{array}$ \\
\hline Paul & New & $<1$ & Active & $2011-2015$ & {$[25,44]$} & Group \\
\hline Kelly & New & $<1$ & Active & 2011-2015 & {$[25,44]$} & Group \\
\hline Sandra & New & $<1$ & Active & $2011-2015$ & {$[25,44]$} & One-on-one \\
\hline Alan & New & $<1$ & Active & 2011-2015 & {$[25,44]$} & One-on-one \\
\hline Mary & New & $<1$ & Inactive & $2007-2010$ & $>64$ & Group \\
\hline Rob & Returning & {$[1,3]$} & Inactive & $2007-2010$ & $>64$ & Group \\
\hline $\mathrm{Ed}$ & Returning & {$[1,3]$} & Active & 2011-2015 & {$[45,64]$} & One-on-one \\
\hline Dan & Returning & $>3$ & Active & 2007-2010 & {$[45,64]$} & One-on-one \\
\hline Sarah & Returning & $>3$ & Inactive & $2007-2010$ & {$[45,64]$} & Group \\
\hline Christine & Returning & $>3$ & Inactive & $2007-2010$ & $>64$ & Group \\
\hline Duncan & Returning & $>3$ & Inactive & $2007-2010$ & $>64$ & Group \\
\hline Vicky & Experienced & $>3$ & Active & $2007-2010$ & {$[25,44]$} & One-on-one \\
\hline Carol & Experienced & $>3$ & Active & $2007-2010$ & {$[45,64]$} & One-on-one \\
\hline Mike & Experienced & $>3$ & Active & $2007-2010$ & {$[45,64]$} & One-on-one \\
\hline Andy & Experienced & $>3$ & Active & $2007-2010$ & {$[45,64]$} & One-on-one \\
\hline Linda & Experienced & $>3$ & Active & $2007-2010$ & {$[45,64]$} & One-on-one \\
\hline Tom & Experienced & $>3$ & Active & $2007-2010$ & $>64$ & One-on-one \\
\hline Gary & Experienced & $>3$ & Active & $2007-2010$ & $>64$ & One-on-one \\
\hline
\end{tabular}




\section{Appendix B. Interview schedule}

- Introduction of the researcher and research aims

- Anonymity, data protection and informed consent: invite the respondent to read and sign the consent form

- Interview questions:

1. First, I was wondering if you could tell me how you became involved in SOS Puffin?

\section{Motivations:}

2. For what reasons did you decide to take part in the project initially?

3. \{If taken part several times What made you want to stay involved in SOS Puffin? \{If taken part once or haven't in a long time\}, do you intend to take part again? If so, what makes you want to stay involved in SOS Puffin? If not, why not?

a. What do you/did you enjoy about volunteering in SOS Puffin?

b. What do you/did you find less enjoyable?

c. What, if anything, makes/made your involvement in SOS Puffin difficult?

\section{Experiences:}

4. What are your most significant or most memorable experiences as a volunteer in SOS Puffin?

a. Looking at these pictures from the islands and work parties, which pictures best represent your experience in SOS Puffin?

b. Why did you select these pictures? What do these pictures bring to mind?

c. What would you have photographed if you had been asked to take a picture representing your experience in SOS Puffin?

Changes:

5. What, if anything, has changed in your view of SOS Puffin over the time of your involvement/after taking part in a work party?

a. What, if anything, has changed in your expectations of the project?

b. In your understanding of the project?

c. In the way you see your role in the project?

6. What, if anything, has changed in your involvement in SOS Puffin?

a. In how often you go to the islands?

b. In your role in the project? 
c. In your interest in the project?

7. What, if anything, has changed in your relationships with other people involved in SOS Puffin?

a. Other volunteers?

b. The organisers?

8. What, if anything, has changed in the way you see the islands and the area?

a. In your knowledge of the islands and the area?

b. In the way you see nature on the islands?

c. In your view of tree mallow?

d. In the importance of the islands and the area to you?

9. What, if anything, has changed in your view of nature conservation as a result of your involvement in the project?

a. In your expectations of nature conservation?

b. In your understanding of nature conservation?

c. In your interest in nature conservation?

d. In what you do to help the environment?

10. What, if anything, have you learned during your involvement in SOS Puffin?

Suggestions and further comments:

11. In your view, what, if anything, could be changed in SOS Puffin?

a. To keep SOS Puffin volunteers motivated?

b. To help the environment?

12. Is there anything else you would like to add about your motivations or your experience in SOS puffin?

Personal information [if not given in the questionnaire]

Age; occupation; level of education/highest qualification; place of residence;

involvement in other volunteering activities

Thank you very much for taking the time to share your experience and suggestions during this discussion [and in the questionnaire]. Do you have further questions or comments about this research project? 
Table 1. Main motivations, perceptions, interests, and relationships during the volunteering process (based on the repeated survey and interview data)

\begin{tabular}{|c|c|c|c|c|c|}
\hline $\begin{array}{c}\text { Level of } \\
\text { experience }\end{array}$ & Motives and positive experiences & $\begin{array}{l}\text { Reasons for } \\
\text { becoming inactive } \\
\text { and negative } \\
\text { experiences }\end{array}$ & $\begin{array}{c}\text { Perception of the } \\
\text { project }\end{array}$ & $\begin{array}{c}\text { Interest in local } \\
\text { nature } \\
\text { conservation }\end{array}$ & $\begin{array}{c}\text { Relationship with } \\
\text { the organisation } \\
\text { and other } \\
\text { participants }\end{array}$ \\
\hline $\begin{array}{l}\text { Prospective } \\
\text { volunteers }\end{array}$ & $\begin{array}{l}\text { Help puffins, nature, and local } \\
\text { environment } \\
\text { Visit the islands and nature (novelty) } \\
\text { Meet people, be with friends/family } \\
\text { Learn, career development } \\
\text { Convenience }\end{array}$ & $\begin{array}{l}\text { Personal } \\
\text { circumstances } \\
\text { Cancellation of boat } \\
\text { ride }\end{array}$ & $\begin{array}{l}\text { Limited knowledge } \\
\text { Expectation of short- } \\
\text { term end-point }\end{array}$ & $\begin{array}{l}\text { Affection for } \\
\text { puffins and } \\
\text { interest in } \\
\text { seabird islands } \\
\text { and local area }\end{array}$ & $\begin{array}{l}\text { Signed up with } \\
\text { close acquaintances } \\
\text { Volunteer for SSC } \\
\text { or local wildlife } \\
\text { group }\end{array}$ \\
\hline $\begin{array}{c}\text { New } \\
\text { volunteers }\end{array}$ & $\begin{array}{l}\text { Feeling of doing my bit for wildlife } \\
\text { See tangible outcomes } \\
\text { Escape, adventure, peace of mind } \\
\text { Exercise, fresh air } \\
\text { Unusual and privileged experience } \\
\text { Conviviality } \\
\text { Learn } \\
\text { Good organisation }\end{array}$ & $\begin{array}{l}\text { Personal } \\
\text { circumstances } \\
\text { Physicality of the } \\
\text { work and } \\
\text { environment } \\
\text { Cancellations, } \\
\text { uncertainty of boat } \\
\text { trip } \\
\text { Size of the task }\end{array}$ & $\begin{array}{l}\text { Longer term than } \\
\text { expected but (a) } \\
\text { progress, or (b) } \\
\text { scepticism }\end{array}$ & $\begin{array}{l}\text { More familiar } \\
\text { with and } \\
\text { interested in the } \\
\text { islands and the } \\
\text { area }\end{array}$ & $\begin{array}{l}\text { Became impressed } \\
\text { by leadership and } \\
\text { people's } \\
\text { commitment } \\
\text { Peripheral to } \\
\text { project }\end{array}$ \\
\hline $\begin{array}{l}\text { Returning } \\
\text { volunteers }\end{array}$ & $\begin{array}{l}\text { Feeling of doing my bit for wildlife } \\
\text { See tangible outcomes } \\
\text { Escape, adventure, peace of mind } \\
\text { Exercise, fresh air } \\
\text { Privileged experience and each trip is } \\
\text { different } \\
\text { Conviviality }\end{array}$ & $\begin{array}{l}\text { Physicality of the } \\
\text { work and } \\
\text { environment, } \\
\text { combined with } \\
\text { health issues } \\
\text { Other personal } \\
\text { circumstances }\end{array}$ & $\begin{array}{l}\text { Longer term than } \\
\text { expected but (a) } \\
\text { progress, or (b) } \\
\text { scepticism }\end{array}$ & $\begin{array}{l}\text { More committed } \\
\text { Possessiveness } \\
\text { Proud of } \\
\text { knowing the } \\
\text { islands }\end{array}$ & $\begin{array}{l}\text { Became impressed } \\
\text { by leadership and } \\
\text { people's, } \\
\text { commitment, } \\
\text { loyalty } \\
\text { Occasional helpers } \\
\text { between casual and }\end{array}$ \\
\hline
\end{tabular}




\begin{tabular}{|c|c|c|c|c|c|}
\hline & $\begin{array}{l}\text { Loyalty, responsibility } \\
\text { Learn } \\
\text { Good organisation }\end{array}$ & $\begin{array}{l}\text { Cancellations, } \\
\text { uncertainty of boat } \\
\text { trip }\end{array}$ & & & $\begin{array}{l}\text { core group } \\
\text { members } \\
\text { Aspirations to be } \\
\text { part of core group }\end{array}$ \\
\hline $\begin{array}{l}\text { Experienced } \\
\text { volunteers }\end{array}$ & $\begin{array}{l}\text { Feeling of doing my bit for wildlife } \\
\text { See tangible outcomes } \\
\text { Escape, adventure, peace of mind } \\
\text { Exercise, fresh air } \\
\text { Privileged experience and each trip is } \\
\text { different, new opportunities for } \\
\text { involvement and learning } \\
\text { Conviviality } \\
\text { Loyalty, duty } \\
\text { Finish a task I have started, } \\
\text { determination }\end{array}$ & $\begin{array}{l}\text { Cancellations and } \\
\text { fewer work parties } \\
\text { being organised }\end{array}$ & $\begin{array}{l}\text { Longer term than } \\
\text { expected but } \\
\text { progress (notably in } \\
\text { recent years) }\end{array}$ & $\begin{array}{l}\text { More committed } \\
\text { Possessiveness } \\
\text { Importance to } \\
\text { one's identity }\end{array}$ & $\begin{array}{l}\text { Loyalty } \\
\text { Occasional helpers } \\
\text { and leaders }\end{array}$ \\
\hline $\begin{array}{c}\text { Inactive } \\
\text { volunteers }\end{array}$ & $\begin{array}{l}\text { Being kept informed of progress and } \\
\text { opportunities }\end{array}$ & $\begin{array}{l}\text { Personal } \\
\text { circumstances } \\
\text { Cancellations } \\
\text { Not feeling needed }\end{array}$ & $\begin{array}{l}\text { Longer term than } \\
\text { expected but (a) } \\
\text { progress, or (b) } \\
\text { scepticism }\end{array}$ & $\begin{array}{l}\text { Fond memories } \\
\text { of the islands } \\
\text { and on-going } \\
\text { interest } \\
\text { Regular visits to } \\
\text { North Berwick }\end{array}$ & $\begin{array}{l}\text { Keep in touch } \\
\text { through reports }\end{array}$ \\
\hline
\end{tabular}




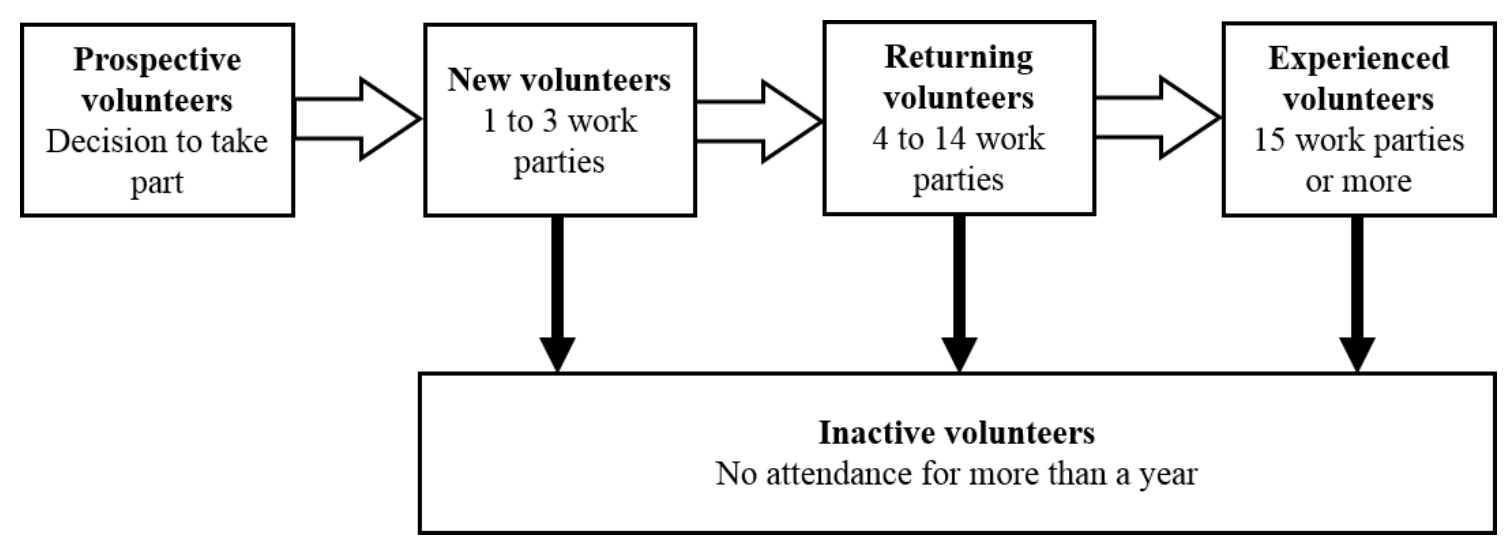

Figure 1. The volunteering process and levels of experience of SOS Puffin participants

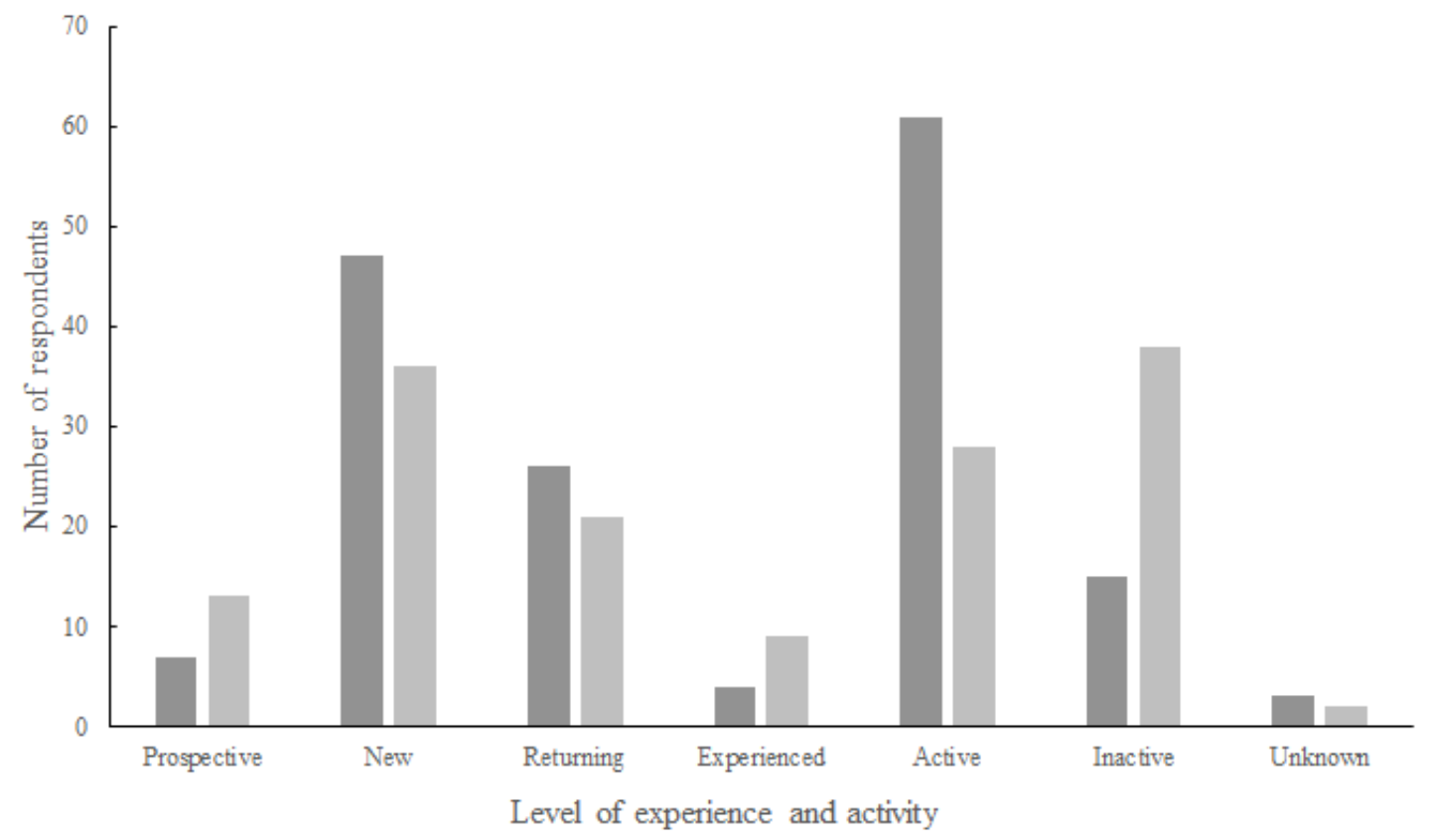

Figure A1. Characteristics of the 2010 and 2014 survey respondents (2010 survey in dark grey; 2014 survey in light grey) 